\title{
As alterações legislativas do código de trânsito brasileiro
}

\section{The legislative alterations of traffic code}

\author{
Julyver Modesto de Araújo'
}

\begin{abstract}
Araújo JM de. As alterações legislativas do código de trânsito brasileiro. Saúde, Ética \& Justiça. 2007;12(1/2):1-4.
RESUMO: O atual Código de Trânsito Brasileiro (CTB) vigora desde 23/09/1997. Desde então, sete leis que alteram o referido código foram aprovadas. O uso de películas nos vidros dos autos, a obrigatoriedade do kit de primeiros socorros e a penalização relacionada à não observância de limites de circulação são alguns dos temas presentes nas leis propostas. O autor observa que o número de propostas de alteração do CTB é grande - só em janeiro de 2007 foram arquivadas 306 - e que, geralmente, essas propostas não representam reais contribuições ao aperfeiçoamento do Código; ao contrário disso, elas têm acrescentado maior confusão. $\mathrm{O}$ autor sugere ainda que as boas idéias devam ser aproveitadas como emendas às propostas já em tramitação.
\end{abstract}

DESCRITORES: Código de Trânsito Brasileiro, legisladores, leis.

$\mathrm{D}$ ispõe o artigo 22, inciso $\mathrm{XI}$, da Constituição Federal de 1988, que "Compete privativamente à União legislar sobre ... trânsito e transporte"; a primeira necessária explicação ao que nos interessa é que a competência privativa difere da competência exclusiva para legislar, posto que, enquanto esta é indelegável, aquela pode ser delegada, fato que se confirma no próprio texto da Carta magna, já que o parágrafo único do mesmo dispositivo estabelece que Lei complementar poderá autorizar os Estados a legislar sobre questões específicas das matérias relacionadas neste artigo.
É por esta previsão constitucional que o nosso Código de Trânsito é Brasileiro e, portanto, vale para todo o território nacional, tendo sido instituído por uma Lei Federal, de no 9.503, promulgada em 23/09/97, sendo incabível que cada município ou cada ente federativo (ressalvado se este for autorizado, mediante lei complementar) pretenda criar o seu próprio Código de Trânsito. Aliás, outra não é a tônica do artigo $1^{\circ}$ do CTB, ao estabelecer que $O$ trânsito de qualquer natureza nas vias terrestres do território nacional, abertas à circulação, rege-se por este Código".

É fato, porém, que as peculiaridades regionais

1 1ํ Tenente da Polícia Militar do Estado de São Paulo. Conselheiro do CETRAN/SP e membro do Fórum Consultivo do Sistema Nacional de Trânsito, Bacharel em Direito, Pós-graduado em Direito Público pela Escola Superior do Ministério Público e Mestrando em Direito Administrativo pela PUC/SP, Coordenador e Professor do Curso de Pósgraduação lato sensu em "Gestão e Normatização de Trânsito" do CEAT.

Endereço para correspondência: http://www.ceatt.com.br 
Araújo JM de. As alterações legislativas do código de trânsito brasileiro.

permitem aos diversos órgãos de trânsito (mas não aos legisladores locais, por incrível que pareça), na esfera de suas competências, a implantação e adoção de normas próprias, desde que estas não conflitem com a legislação federal aplicável ao assunto e estejam, logicamente, na sua alçada de atribuições. Veja-se, a este aspecto, que o Sistema Nacional de Trânsito, previsto no artigo $7^{\circ}$ do CTB, compreende órgãos considerados normativos, que são os Conselhos de Trânsito (CONTRAN, CONTRANDIFE e CETRANs), entre cujas competências compreendese a atribuição de elaboração de normas administrativas complementares ao Código, nos termos dos artigos 12, inciso I, e 14, inciso II. Além deles, mesmo os órgãos denominados executivos (de trânsito ou rodoviários) possuem a determinação legal em torno do estabelecimento de procedimentos internos, a justificar a elaboração de Portarias regulamentares de suas atividades.

Não queremos, entretanto, neste momento, nos aprofundar no caráter regulamentador dos órgãos administrativos, mas nos interessa avaliar as alterações legislativas do Código de Trânsito Brasileiro, que, como visto no início, dependem do competente processo legislativo federal, com aprovação de projeto de lei respectivo no Congresso Nacional (Câmara dos Deputados e Senado Federal) e posterior sanção do Exmo. Sr. Presidente da República, eis se tratar do Chefe do Poder Executivo em cuja seara se encontra a competência legislativa abordada.

Desde a promulgação da Lei oㅜ 9.503/97, sete foram as Leis aprovadas que alteraram artigos do Código de Trânsito (9.602/98; 9.792/99; 10.350/01; $10.517 / 02$; $10.830 / 03$; $11.275 / 06$ e $11.334 / 06$ ); infelizmente, porém, nem todas as modificações proporcionadas por nossos legisladores atenderam às expectativas técnico-jurídicas dos profissionais de trânsito, que, mais do que ninguém, almejam uma legislação justa, equilibrada e coesa. A este respeito, interessante comentar que o anteprojeto de lei que deu origem ao atual CTB partiu do Poder Executivo, por intermédio de Comissão especialmente firmada em 1991, passando pelo crivo, com poder terminativo, das Comissões da Câmara dos Deputados e Senado Federal, mas sem votação em plenário (de todos os parlamentares).

Já as Leis posteriores não tiveram a mesma tramitação, seja pela origem, seja pelo tempo destinado à discussão da matéria (o que é até compreensível, mas acarreta uma preocupação no que se refere à necessária coesão entre as propostas apresentadas e o texto integral do CTB, nem sempre protegida).

A primeira alteração legislativa, aliás, foi publicada justamente no dia em que entrou em vigor a própria norma que estava sendo alterada, isto é, o CTB passou a vigorar em 22/01/98, já com as alterações decorrentes da Lei $n^{\circ}$ 9.602/98, publicada na mesma data.

A Lei 9.602/98, ressalta-se, foi a que mais alterou dispositivos do Código de Trânsito (entre acréscimos e revogações, foram modificados exatamente doze artigos): algumas incongruências se despontam justamente pela falta de coesão anteriormente comentada, como os exemplos a seguir enumerados.

A aplicação de películas nos vidros dos veículos, por exemplo, passou a ser autorizada desde que não comprometesse a segurança do trânsito, na forma de regulamentação do CONTRAN, com a inclusão do inciso III ao artigo 111; entretanto, não houve a devida adequação ao artigo 230 , inciso XVI, que trata da infração de trânsito e tinha como premissa a total proibição estabelecida pelo inciso I do artigo 111, retirado do texto legal por veto presidencial.

Compare os dispositivos mencionados e perceberá que acabaram sendo, de certa forma, conflitantes:

Art. 111 - É vedado, nas áreas envidraçadas do veículo:

I - a aposição de inscrições, películas refletivas ou não, adesivos, painéis decorativos ou pinturas, salvo as de caráter técnico necessárias ao funcionamento do veículo (VETADO).

III - aposição de inscrições, películas refletivas ou não, painéis decorativos ou pinturas, quando comprometer a segurança do veículo, na forma de regulamentação do CONTRAN (INCLUÍDO PELA LEI № 9.602/98).

Art. 230, XVI - Conduzir o veículo com vidros total ou parcialmente cobertos por películas refletivas ou não, painéis decorativos ou pinturas:

Infração - grave. Penalidade - multa.

Medida administrativa - retenção do veículo para regularização.

O inciso Il do artigo 187 foi revogado, tornando o dispositivo um tanto quanto mutilado, já que não há mais razão para sua divisão, podendo a descrição da infração constar unicamente do caput do artigo 187, o que não ocorre (porque não foi assim mencionado na Lei 9.602/98).

Veja: Art. 187 - Transitar em locais e horários não permitidos pela regulamentação estabelecida pela autoridade competente:

I - para todos os tipos de veículos:

Infração - média.

Penalidade - multa. 
Nota: o inciso II previa infração grave "especificamente para caminhões e ônibus".

No artigo 269, outro exemplo: tivemos a inclusão de uma medida administrativa totalmente desfocada de todas as outras lá constantes, já que o artigo trata de medidas, que, a rigor do artigo 161, devem ser aplicadas conforme indicação nas diversas infrações de trânsito; entretanto, ao contrário da remoção e retenção do veículo, bem como do recolhimento do Certificado de Licenciamento Anual ou da Carteira Nacional de Habilitação, por exemplo, que são medidas vinculadas a determinadas infrações, a Lei 9.602/98 acrescentou, naquele dispositivo, a medida de "realização de exames de aptidão física, mental, de legislação, de prática de primeiros socorros e de direção veicular", providência que está ligada, estritamente, à concessão da Carteira Nacional de Habilitação.

No tocante aos recursos de trânsito, mais uma escorregada: prevê o artigo 285 que "O recurso previsto no art. 283 será interposto perante a autoridade que impôs a penalidade, a qual remetê-loá à JARI, que deverá julgá-lo em até trinta dias"; porém, o artigo 283, a que faz menção o texto transcrito foi vetado, sob o argumento da proteção ao direito de ampla defesa, já que este artigo mencionava que a contagem do prazo recursal dar-se-ia a contar da data da IMPOSIÇÃO da penalidade.

Para sanar o veto ao artigo que trataria da interposição de recurso administrativo em primeira instância, a Lei 9.602/98 incluiu os $\S \S 4^{\circ}$ e $5^{\circ}$ ao artigo 282 , com os mesmos dizeres do artigo 283 , substituindo o marco referencial da IMPOSIÇÃO da penalidade para a data da NOTIFICAÇÃO da penalidade; todavia, deixou de consignar que, no artigo 285, a referência que lá constava não mais deveria ser o artigo 283 e sim o § $4^{\circ}$ do artigo 282.

A segunda Lei que alterou o CTB foi a Lei no 9.792/ 99, da qual me abstenho de comentar, já que apenas revogou o artigo 112 do Código, o qual obrigava o porte do conjunto de primeiros socorros (lembra-se?), assim como não tenho muito o que pautar sobre as duas Leis seguintes (10.350/01 e 10.517/02), que pouco modificaram o texto anterior, limitando-se a versar, respectivamente, sobre o exame psicológico para renovação da habilitação dos motoristas que executam transporte remunerado e a possibilidade de tracionamento de semi-reboques por motocicletas (v. artigos 147, §§ $3^{\circ}$ e $5^{\circ}$, e 244, , $3^{\circ}$ ).

A Lei no 10.830/03, porém, embora de redação bem curta (já que parte do projeto apresentado foi barrado no Congresso), acabou deixando de lado outros aspectos que poderiam ter sido abrangidos, na tentativa de criar uma regra mais justa, no estabelecimento de velocidade nas rodovias não sinalizadas. Assim dispunha o artigo 61, § 1ํ, inciso II, a), antes da alteração desta lei:

"Art. 61 - A velocidade máxima permitida para a via será indicada por meio de sinalização, obedecidas suas características técnicas e as condições de trânsito.

$\S 1^{\circ}$ - Onde não existir sinalização regulamentadora, a velocidade máxima será de:

II - nas vias rurais:

a) nas rodovias:

1) cento e dez quilômetros por hora para automóveis e camionetas;

2) noventa quilômetros por hora, para ônibus e microônibus;

3) oitenta quilômetros por hora, para os demais veículos;"

A Lei 10.830/03 nada mais fez que incluir as motocicletas no item 1), já que, da maneira como estava redigido o dispositivo alterado, teríamos que conceber tais veículos como incursos no item 3), como sendo "demais veículos". A alteração é justa (embora discutível), já que muitas motocicletas são capazes (analisando-se apenas mecanicamente) de serem conduzidas na mesma velocidade que os automóveis; contudo, deixou o legislador de reconhecer o mesmo aspecto para os triciclos, por exemplo, e, pior, para as caminhonetes, que, a rigor das conceituações do Anexo I do CTB, são diferentes das camionetas e, portanto, incluem-se no item 3 (independente da capacidade motora):

CAMINHONETE - veículo destinado ao transporte de carga com peso bruto total de até três mil e quinhentos quilogramas.

CAMIONETA - veículo misto destinado ao transporte de passageiros e carga no mesmo compartimento.

Finalmente, as duas últimas Leis $(11.275 / 06 \mathrm{e}$ 11.334/06), por coincidência de autoria do mesmo parlamentar (Exmo. Sr. Deputado Federal Beto Albuquerque), carecem, data venia, da mesma coesão já cobrada, em relação ao texto integral do Código de Trânsito.

No que se refere à Lei no 11.275/06, que trata da embriaguez ao volante, chamo a atenção para dois aspectos principais: em primeiro lugar, apesar de o índice de seis decigramas de álcool por litro de sangue ter sido retirado da referência da infração de trânsito do artigo 165, bem como da regra geral que versa sobre a realização de exames de constatação (artigo 277), não houve qualquer revogação deste critério, 
Araújo JM de. As alterações legislativas do código de trânsito brasileiro.

que se encontra registrado no artigo antecedente (276), gerando-se discussões sobre a sua revogação tácita (já que não foi expressa, mas contraria o espírito da nova lei); em segundo lugar, destaco a imprecisão da expressão utilizada no atual $\S 2^{\circ}$ do artigo 277 , que autoriza, no caso de recusa do condutor à realização de testes de constatação da influência de álcool, entorpecentes e substância análogas, a caracterização da infração mediante a obtenção de "outras provas em direito admitidas" pelo agente de trânsito, o que, igualmente, tem sido motivo de debates, já que até mesmo a confissão é uma prova admitida em direito, ao lado da prova documental, pericial e testemunhal, por exemplo.

No caso da Lei nํ 11.334/06, que alterou o artigo 218 do CTB, o qual versa sobre a infração de excesso de velocidade, já escrevi sobre o tema, em outra oportunidade, em artigo intitulado "Novas regras para a fiscalização de velocidade - Comentários sobre a Lei $\mathrm{n}^{\circ}$ 11.334/06", apontando as diversas incongruências do texto aprovado, em que destaco, por ora, as penalidades previstas no atual inciso III do artigo 218: (multa [3 (três) vezes], suspensão imediata do direito de dirigir e apreensão do documento de habilitação), tendo em vista que, além de não existirem estas penalidades no artigo 256 do CTB, a suspensão do direito de dirigir não pode ser imediata, por contrastar com o princípio da ampla defesa, consignado no artigo 5으, inciso LV, da Constituição Federal e no artigo 265 do próprio Código de Trânsito.

Se até aqui o leitor teve paciência para acompanhar os comentários deste articulista, considerando-me por demais detalhista na análise e interpretação de nossa legislação de trânsito e está achando que foram muitas as proposições para alteração de um Código que tem "apenas" quase dez anos de vida (muito recente, se comparado com o Código anterior, que vigorou por pouco mais de trinta anos), apresso-me em alertar que a criatividade de nossos legisladores não se encerra por aqui, havendo, atualmente, nada menos que 34 projetos de lei em tramitação na Câmara dos Deputados, para alteração do Código de Trânsito (destes, 12 já se encontram no Senado Federal). E mais: só nos livramos de outros 306 projetos, que deixariam ainda mais retalhado nosso Código de Trânsito, porque estes foram arquivados ao final do mês de janeiro de 2007, em obediência ao que dispõe o artigo 105, parágrafo único, do Regimento interno da Câmara dos Deputados, que determina o arquivamento de todas as proposições em tramitação, finda a legislatura, salvo as I) com pareceres favoráveis de todas as comissões; II) já aprovadas em turno único, em primeiro ou segundo turno; III) que tenham tramitado no Senado, ou dele originárias; IV) de iniciativa popular, e V) de iniciativa de outro Poder ou do Procurador Geral da República.

Ressalto, entretanto, que o desarquivamento pode ser feito nos primeiros 180 dias da primeira sessão legislativa da próxima legislatura, que se iniciou em 01/02/07, mas somente por requerimento do autor e desde que este tenha sido reeleito (dos 306 projetos arquivados, 131 poderão, nestas circunstâncias, ser colocados novamente em pauta).

Comentar cada um destes projetos seria, sem dúvida, um ótimo exercício jurídico, mas prefiro deixar para outra ocasião, ressaltando, apenas, que as propostas apresentadas revestem-se, em geral, de uma peculiaridade muito interessante, pois dificilmente procuram melhorar as regras já existentes e/ou consertar os erros do nosso Código de Trânsito, mas, ao contrário, trazem ainda mais confusão e contrariedades, não havendo, nem mesmo, consenso entre nossos representantes, para que projetos não sejam apresentados desnecessariamente, aproveitando-se as (boas) idéias como emendas à propostas já em tramitação (para se ter uma idéia, só sobre equipamentos eletrônicos de fiscalização, contabilizei quase 50 projetos de lei que estavam em tramitação e que, por enquanto, foram para os arquivos da Câmara dos Deputados).

Araújo JM de. The legislative alterations of traffic code. Saúde, Ética \& Justiça. 2007;12(1/2):1-4.

ABSTRACT: The current Brazilian Traffic Code came into force on September $23^{\text {rd }}$ of 1997. Since then, seven laws that amend the code have been approved. The use of tinted windows, the mandatory first-aid kit and the penalization related to the disregard of circulation limits are some of the themes present in the laws passed. The author observes that the number of propositions of amendments to the code is high - only in January of 2007, 306 of such propositions were archived- and that, in general, these propositions do not represent real contributions to the improvement of the Code; they actually have the opposite effect, of adding to the confusion. The author further suggests that the good ideas should be incorporated as amendments to those propositions already submitted for approval.

KEY WORDS: Brazilian Traffic Code. Legislators. Llaws. 